\title{
EXPLORING SEXUAL PRACTICES OF SOUTH AFRICAN SOLDIERS TO DETERMINE THEIR VULNERABILITY TO THE HUMAN IMMUNE-DEFICIENCY VIRUS
}

\author{
ANGELA DE JONG \\ angeladejong@telkomsa.net \\ DELÉNE VISSER \\ jdv@eb.rau.ac.za \\ Department of Human Resource Management \\ University of Johannesburg
}

\begin{abstract}
Although HIV occurs in all social groups in South African society, certain populations are more vulnerable to HIV through risky behaviour patterns. Of relevance to the present study, are the high risk situations that deployed soldiers are exposed to. Three issues indicated the necessity for a study of this kind to be conducted; (a) the statistics pointing to a higher incidence of HIV infections among military personnel than among the general population, (b) military personnel's unique vulnerability profile, and (c) the South African National Defence Force's (SANDF) increasing participation in international peacekeeping missions. The knowledge, attitudes and practices concerning HIV/AIDS of deployed soldiers were analysed. Results indicated that soldiers were taking sexual risks, although they had high levels of knowledge and had healthy attitudes concerning HIV/AIDS.
\end{abstract}

Key words

Deployment of soldiers, HIV/AIDS vulnerability, risk-taking sexual behaviour

Several studies conducted by Okee-Obong (2001) confirmed that there is an association between work in the military and high risk sexual activity. Ministries of Defence of countries in Sub-Saharan Africa reported HIV incidence averages of $20 \%$ to $40 \%$ within their armed services, and rates of $50 \%$ to $60 \%$ in countries where HIV/AIDS had been present for more than a decade (Curran \& Munywoki, 2002). A study of Nigerian peacekeepers returning from Sierra Leone and Liberia indicated that HIV incidence among military personnel was $11 \%$, whereas HIV incidence in the adult population of Nigeria was $5 \%$ at that time (Olayinka \& Osho, 1997). In South Africa, the Mail and Guardian newspaper (2000) reported that HIV incidence among South African military personnel was between $60 \%$ and $70 \%$ as compared to $20 \%$ among the general South African adult population. Results from surveys conducted in 1995 estimated the infection rate for the Zimbabwean armed forces at three to four times higher than the level in the civilian population (UNAIDS, 1998a). The HIV/AIDS incidence in the uniformed services (military and police) in Tanzania was estimated to be between $15 \%$ and $16 \%$, which was also higher than the national incidence (Curran \& Munywoki, 2002). Studies of sexual behaviour conducted in France, the United Kingdom and United States showed that military personnel from the developed world also had a much higher risk of HIV infection than groups of comparable age and sex in the civilian population (UNAIDS, 1998a).

Craig and Le Roux (2002) identified the high risk factors that soldiers were exposed to as multiple sexual relationships, social norms accepting high numbers of sexual partners, low status of women in society and in relationships, making use of commercial sex workers, resistance to condom use, frequent use of intoxicating substances, separation of individuals from their families, living in single-sex quarters, presence of other sexually transmitted infections and exposure to poverty during deployment. Research conducted by the Joint United Nations Programme on HIV/AIDS (UNAIDS) also delivered a comprehensive list of factors that increased soldiers' HIV vulnerability. These risk factors are discussed in more detail hereafter.

Military personnel's unique vulnerability profile

The UNAIDS (2001a) observed that one of the characteristics that many voluntary mobile individuals such as deployed soldiers shared, was that they were risk takers. Essentially, they took a risk by believing that a different environment would be beneficial to them. Their willingness to take risks subsequently influenced the choices that they made in their private lives (UNAIDS, 2001a). Furthermore, mobile workers' geographic mobility lowered their chances of creating stable relationships with women in the host culture (Bruwer \& Van Dyk, 2005; Shtarkshall \& Soskolne, 2000). Loneliness, frustration and peer pressure combined with access to drugs, alcohol or sex workers prompted them to take risks and engage in behaviour they would not have engaged in at home. The anonymity of being a foreigner also freed mobile workers from the social norms that guided their behaviour when they were with their families, or in their communities and cultures (UNAIDS, 2001a). Moreover, drug dealers or sex workers exploited these circumstances (Duckett, 2001). Single-sex migration also led to increased sex among men (Curran \& Munywoki, 2000).

The consequence of single-sex migration was that living and recreational environments for deployed soldiers were almost exclusively male (UNAIDS, 2001a). This often led to the development of commercial sex services and the pressure to use them (Curran \& Munywoki, 2000). Lurie's observation in a 1999 article in the Village Voice was: 'If you wanted to spread a sexually transmitted disease, you'd take thousands of young men away from their families, isolate them in single-sex hostels, and give them easy access to alcohol and commercial sex. Then, to spread the disease around the country, you'd send them home every once in a while to their wives and girlfriends' $(1999$, p. 23).

Posting soldiers far from their families for long time periods The factor cited most often as leading to high rates of STI's and HIV in the military, was the practice of posting personnel far from their families for long periods of time (UNAIDS, 1998a). These soldiers were separated from normal family life whilst having easy access to alcohol and other intoxicating substances (Bielfeld, 2002). Deployed soldiers were further found to be at risk of HIV infection, because they tended to be subject to high stress periods, interspersed with long periods of boredom (UNAIDS, 1998b). Being less subject to social controls, deployed soldiers tended to relax by abusing alcohol and drugs. Furthermore, sex worker or drug dealer networks frequently operated close to bases, because they knew that soldiers had adequate financial means to purchase their services or products (Bielfeld, 2002). 
Access to intoxicating substances and sex workers

Results of a study conducted by De Beer (2002) indicated that deployed soldiers used alcohol to relax, especially during long periods of boredom, because it was readily available and sold at a reduced tariff. Moreover, soldiers who were deployed tended to drink five times more than what they would drink if they were not deployed (A. Falksen, personal communication, 16 September 2003). The presence of sex workers was also noted around military bases, both within and outside the borders of South Africa (De Beer, 2002).

\section{Relative young age of soldiers}

Another factor that increased their vulnerability was that soldiers were mostly young and sexually active (UNAIDS, 1998a). Most military personnel globally fall in the age group at greatest risk for HIV infection (Curran \& Munywoki, 2000). Additionally, local populations in remote regions often perceived the young, fit, apparently healthy and clean soldiers dressed in uniform as attractive sexual partners (Curran \& Munywoki, 2000). A study of Dutch sailors and marines on peacekeeping duty in Cambodia showed that $45 \%$ reported having sexual contact with sex workers or other members of the local population during a five-month tour (UNAIDS, 1998a). Similarly, a study revealed that $10 \%$ of the United States naval personnel and marines contracted new STI's during trips to South America, West Africa and the Mediterranean during 1989 to 1991 (UNAIDS, 1998b). However, military personnel are a vulnerable group not only because of their relative youth, but their risk taking attitudes also have an impact on their vulnerability levels.

\section{Risk taking attitudes as part of the military culture}

Risk taking attitudes include those attitudes consciously influenced during training and also those that are learnt informally as part of the military 'risk-taking culture' (UNAIDS, 1998a). Furthermore, the UNAIDS (1998b) observed that the military's professional ethos tends to excuse or even encourage risk taking. Although willingness to accept risk is crucial in combat, the same attitude increases soldiers' willingness to engage in unnecessary high risk sexual behaviour. Moreover, the UNAIDS (2002) found that soldiers were governed more by peer pressure than moral convention and were inclined to feel invincible. Consequently they took high risks. Because they were fit, physically active and armed, they believed they were invulnerable, even to infectious diseases (Curran \& Munywoki, 2000).

\section{Sexual risk practices}

The emphasis on sexual prowess as the 'mark of a man' further motivated soldiers to pursue sex with many partners, because they perceived it as a type of 'conquest' (Curran \& Munywoki, 2000). In addition, the sense of prestige that accompanied wearing a uniform tempted soldiers to view civilians, especially women, as individuals over whom they had power (UNAIDS, 1998a). This increased the probability of soldiers becoming involved in anonymous, paid-for or coercive sexual practices (UNAIDS, 1998a). For instance, Curran and Munywoki (2000) found that when community members in Kenya, Tanzania and Uganda sought the protection of the armed services, it was often granted in exchange for sex. Income disparity also increases HIV vulnerability among deployed soldiers. Curran and Munywoki (2000) found that when soldiers deployed in remote areas, they usually earned substantially more than the local population and were therefore targeted by women who needed to earn money to survive. Deployed soldiers often formed relationships with the local women and when the latter fell pregnant, they were usually not integrated into the extended family. This resulted in a negative cycle of women needing to earn money under difficult circumstances. In many instances these women resorted to prostitution (UNAIDS, 2001a).

Exposure to disrupted environments during deployment Deployment to unsettled areas greatly increased military personnel's chances of acquiring HIV, because they were not only exposed to socially disrupted environments, but also to the possibility of infection through wounding or contact with contaminated blood (Masibambisane, 2001; Van Breda, Siwisa, Potgieter \& Banda, 1999). On their return, transmission of the virus to spouses, partners, sex workers and other members of the community was a serious risk, particularly during the window period (Curran \& Munywoki, 2000). Through unscreened blood donations or by the sharing of infected needles infected military personnel also transmitted the disease to the wider community (UNAIDS, 2001a). Transmission to medical personnel occurred when the latter came into contact with contaminated blood accidentally (UNAIDS, 1998b).

It is clear from the scenarios discussed above that military personnel are often exposed to HIV risk factors due to their mobility and behaviour during the period of mobility. The high risk situations the soldiers are exposed to further increase their vulnerability to STI or HIV infection (Hyde, Moeketsi \& White, 1998). In a report on aspects relating to military readiness in the African context, Malan (1997) identified sexually transmitted diseases, such as HIV/AIDS, as serious debilitating factors on potential unit performance and military readiness. The UNAIDS (1998a) agreed that these diseases compromised military readiness, because the necessary skills and experience of highly trained members were lost due to AIDS and opportunistic infections. This situation created a loss of continuity at the command level, but also within the various ranks, subsequently increasing health care costs, costs with regard to recruitment, and training for replacements (Department of Defence, 2002). The loss of morale due to sexually transmitted diseases also contributed to compromised military readiness (Curran \& Munywoki, 2000).

There is clearly an urgent need to develop and implement more effective workplace-based HIV/AIDS programmes addressing HIV/AIDS among mobile workers such as military personnel. Such programmes should empower soldiers to protect themselves against infection and to reduce transmission of HIV (UNAIDS, 2001a). According to the United Nations General Assembly Special Session on HIV/AIDS (2002) workplace-based HIV/AIDS programmes need to address the following indicators, namely (a) the basic facts on HIV/AIDS, (b) specific work-related HIV transmission hazards and safeguards, (c) the promotion of condom usage, (d) voluntary HIV counselling and testing, (e) diagnosis and treatment of sexually transmitted infections, and (f) provision of HIV/AIDS related drugs. The status of these indicators within the SANDF was determined by measuring the levels of knowledge, attitudes and practices (KAP) of SANDF soldiers. Therefore, the first objective of this study was to determine the existing knowledge levels of deployed soldiers concerning HIV/AIDS and related issues. Secondly, the attitudes of deployed soldiers concerning various aspects of HIV/AIDS, and reported risk taking practices were identified.

\section{RESEARCH DESIGN}

Research approach

A survey-type questionnaire was used as a measure of individuals' sexual behaviours and potential to contract HIV. The data were analysed by means of quantitative statistical techniques.

\section{Respondents}

A representative stratified sample was drawn from the entire Department of Defence (DoD) population. Recent personnel records were requested from the State Information Technology Agency (SITA) to verify the DoD population size and to determine the sizes of the different strata within the current DoD structure. The stratified random sample was drawn from the four Services, including Defence Headquarters, Military Intelligence Division, Chaplain General and Defence 
Secretariat. The nine provinces were proportionally reflected within the sample and further included all headquarters and units, ranks (including the top structure, middle management and operational employees), gender, race (Asian, Black, Coloured and White), and civilian and uniformed members. A ten percent sample was drawn from a population of 79983 members. A total of 8602 questionnaires were distributed in the nine regions, of which 4530 questionnaires were returned and processed. In 163 questionnaires respondents did not respond to the item pertaining to the length of time spent away from home in the year prior to data collection, and these respondents were excluded from the analyses. Therefore 4367 questionnaires were used.

The majority of the respondents were male $(79,5 \%), 34 \%$ of the respondents were between the ages of 25 to 36 years, $47,2 \%$ of the sample was married with one partner, $63,1 \%$ had between one or three children and $54,8 \%$ had obtained a Standard 10 or equivalent educational qualification. Most of the respondents lived in housing that they privately owned (48\%) and 54,2\% reported that their spouses or partners lived with them. A large proportion of the sample indicated that they functioned either in the infantry (26\%) or support within the Army $(26,4 \%)$ and they mainly represented non-commissioned officers $(65,6 \%)$ More than two-thirds of the sample (73\%) reported that they had not been exposed to an HIV/AIDS training course, seminar or work session in the six months or two years prior to data collection. Approximately ten percent of the respondents $(12,8 \%)$ reported that they had been exposed to someone dying of HIV/AIDS. More than eighty percent of the respondents $(86,3 \%)$ indicated that they were sexually active.

\section{Measuring instrument}

A pilot study was conducted to identify potential problems that may have occurred during the main study concerning the format and content of the questionnaire. A small number of questions were reworded, because their wording was found to be unclear. These questions were adjusted for the final questionnaire. On the cover page of the questionnaire the purpose of the questionnaire was stated as '...aimed at finding out your knowledge, attitudes and practices with regard to HIV/AIDS'. It was further explained that the information sought was important in fighting the battle against AIDS and that the respondents' opinions were of great importance. The questionnaire was highly personal and therefore respondents were not required to write their names or force numbers on the questionnaire. Respondents were assured that all information would be kept strictly confidential and would not be revealed in any way that could disclose their identity. It was made clear that the requested biographical information would only be used for purposes of analyses. The questionnaire consisted of a biographical information section and various sections assessing knowledge, attitudes and practices.

Knowledge. In the knowledge section respondents were asked to choose whether statements were true or false. The correct answers are indicated in Table 1 . If the respondents were not sure about an answer, they had the option to choose the 'uncertain' response, but they were requested to rather opt for the true or false response.

Responses in the 'uncertain' category were scored as 'incorrect' answers. This was done, because the items reflect knowledge. Uncertain responses therefore implied that the respondents did not know what the answer was. Missing data were also scored as incorrect answers. If respondents knew the answer, it was assumed that they would provide the correct answer. The possibility existed that the HIV/AIDS related questions could be perceived as being sensitive in nature and that respondents would therefore not be willing to answer the questions. Nevertheless, it was believed that the knowledge questions assessed general HIV knowledge and not personal information.
TABLE 1

\section{CORRECT ANSWERS FOR THE KNOWLEDGE ITEMS}

\begin{tabular}{|c|c|}
\hline Construct & Items \\
\hline \multirow[t]{15}{*}{ HIV in general } & HIV is a virus that causes AIDS (true) \\
\hline & At present there is no cure for HIV/AIDS (true) \\
\hline & $\begin{array}{l}\text { A person can be infected with HIV/AIDS and not even } \\
\text { know it (true) }\end{array}$ \\
\hline & Women are more at risk to get HIV/AIDS than men (true) \\
\hline & HIV/AIDS is a disease that only some race groups get (false) \\
\hline & AIDS and HIV are the same thing (false) \\
\hline & $\begin{array}{l}\text { A Sangoma (traditional or faith healer) can cure HIV/AIDS } \\
\text { (false) }\end{array}$ \\
\hline & HIV/AIDS does not really exist (false) \\
\hline & $\begin{array}{l}\text { Most gay men (men that have sex with men) have } \\
\text { HIV/AIDS (false) }\end{array}$ \\
\hline & $\begin{array}{l}\text { A man can be cured of HIV/AIDS by having sex with a } \\
\text { virgin (false) }\end{array}$ \\
\hline & $\begin{array}{l}\text { Washing your vagina/penis after sex can help prevent you } \\
\text { from getting HIV/AIDS (false) }\end{array}$ \\
\hline & $\begin{array}{l}\text { A woman cannot get HIV/AIDS if she has sex during } \\
\text { menstruation (period/monthly bleeding) (false) }\end{array}$ \\
\hline & $\begin{array}{l}\text { A person can get HIV/AIDS from shaking hands with } \\
\text { someone who already has the disease (false) }\end{array}$ \\
\hline & $\begin{array}{l}\text { A person can get HIV/AIDS from kissing, hugging, and } \\
\text { touching someone who already has HIV/AIDS (false) }\end{array}$ \\
\hline & $\begin{array}{l}\text { You can get HIV/AIDS by sharing eating utensils (a knife or } \\
\text { a cup, etc) with someone who already has HIV/AIDS (false) }\end{array}$ \\
\hline \multirow{3}{*}{$\begin{array}{l}\text { Occupational } \\
\text { health and } \\
\text { safety }\end{array}$} & You can protect yourself from getting infected with \\
\hline & $\begin{array}{l}\text { HIV/AIDS when helping someone who has been injured or } \\
\text { hurt by wearing surgical gloves (true) }\end{array}$ \\
\hline & $\begin{array}{l}\text { Putting plastic bags on your hands will protect you from } \\
\text { getting infected with HIV/AIDS when helping someone } \\
\text { who is bleeding from an injury (true) }\end{array}$ \\
\hline \multirow[t]{3}{*}{$\begin{array}{l}\text { Safe sexual } \\
\text { practices }\end{array}$} & $\begin{array}{l}\text { One way of reducing the risk of getting HIV/AIDS is not to } \\
\text { have sex at all (true) }\end{array}$ \\
\hline & $\begin{array}{l}\text { A person cannot get HIV/AIDS if they have sex with an } \\
\text { infected person only once (false) }\end{array}$ \\
\hline & Not having sex at all will make you mad (false) \\
\hline \multirow[t]{8}{*}{ Condoms } & $\begin{array}{l}\text { When having sex, the best protection against HIV/AIDS is } \\
\text { to use a condom (true) }\end{array}$ \\
\hline & It is important for people to use condoms during sex (true) \\
\hline & $\begin{array}{l}\text { A man should always put a condom on before any contact } \\
\text { with a woman's vagina (private parts) (true) }\end{array}$ \\
\hline & $\begin{array}{l}\text { An oil-based lubricant (such as baby oil or Vaseline) can be } \\
\text { used with a condom (false) }\end{array}$ \\
\hline & The use of a condom during sex can harm your health (false) \\
\hline & Condoms can be used more than once (false) \\
\hline & $\begin{array}{l}\text { The use of a condom during sex can harm the health of } \\
\text { your partner (false) }\end{array}$ \\
\hline & $\begin{array}{l}\text { If your partner or you were pregnant, } \\
\text { using a condom during sexual intercourse could harm the } \\
\text { baby (false) }\end{array}$ \\
\hline
\end{tabular}

The recoded knowledge items were grouped into four construct categories, namely knowledge of HIV in general, occupational health and safety, safe sexual practices and condoms. The knowledge construct was assessed with 31 questions of which 18 questions pertained to general HIV/AIDS knowledge, myths or fables, and two questions identified occupational health and safety related knowledge. An additional three questions measured knowledge relating to safe sexual practices and eight tested knowledge concerning condom use. The appropriate items were summed, total scores were calculated and percentages were computed. Total scores were expressed as percentages to enable one to compare the means and standard deviations of the four knowledge categories, because the numbers of items per category were not equal. The means of the 31 items were summed to calculate an overall knowledge score. The internal consistency reliability coefficient, namely Cronbach's alpha, of the knowledge construct was 0,76 . 
Attitudes. The attitude items were grouped according to safe sexual practices, condoms, workplace and SANDF. Respondents were asked to choose whether they 'strongly agreed', 'agreed', 'disagreed' or 'strongly disagreed' with the statements. If respondents were not sure about an answer, they had the option to choose the 'uncertain/not applicable' response. The 'uncertain/not applicable' response option was treated as missing data.

There were three statements pertaining to safe sexual practices, namely (a) 'I do not think of protecting myself from getting infected with HIV/AIDS', (b) 'HIV/AIDS cannot happen to me', and (c) 'It is impossible for people to change their sexual behaviour to avoid getting HIV/AIDS'. For all three items desirable answers were 'disagree' or 'strongly disagree'.

Five items pertained to attitudes regarding the use of condoms. Responses to the item 'I could get HIV/AIDS if I had sex with a new partner without using a condom' were reversed. The desirable responses for the remaining items in this category were either 'disagree' or 'strongly disagree'. These items were (a) 'Condoms tear or slip, so it is a waste of time to use them', (b) 'Using a condom seems like an insult to my partner', (c) 'When a man and a woman have sex it is the man that has the final say whether a condom is used or not', and (d) 'It is the woman's responsibility to make sure that condoms are used during sex'.

The next category determined respondents' attitudes towards HIV/AIDS concerns within the workplace. The items were (a) 'I would be prepared to work alongside someone who has HIV/AIDS', (b) 'I would feel happy to share a room with someone who has HIV/AIDS during a military course or other course', (c) 'If I had HIV/AIDS, I would be prepared to tell my friends at work about it', (d) 'I would not mind to tell my supervisor at work if I had HIV/AIDS', and (e) 'My feelings towards a friend of mine at work would not change if I learned that he or she had HIV/AIDS'.

Eight items measured attitudes concerning the SANDF's management of the HIV/AIDS epidemic. The three positively worded items measuring attitudes towards the SANDF were (a) 'Members of the SANDF/DoD are tolerant and respectful of people with HIV or AIDS', (b) 'If a member of my unit told everyone that they had HIV/AIDS, they would still be a valued and liked member of the unit', and (c) 'People in the SANDF/DoD who have HIV/AIDS can still enjoy a career in the SANDF'. There were also three negatively phrased items, namely (a) 'As soon as a soldier/employee of the DoD is found to have HIV/AIDS, he or she will loose their job', (b) 'The only purpose of the Concurrent/Comprehensive Health Assessments is to test soldiers for HIV/AIDS', (c) 'The SANDF/DoD tests people for HIV/AIDS to get rid of people it wants to fire', (d) 'All soldiers who are not G1K1 have HIV/AIDS', and (e) 'People in the SANDF/DoD who have HIV/AIDS get better medical care than people with other illnesses such as cancer'.

All the attitude items were coded such that a score of 1 indicated undesirable attitudes and a 4 indicated desirable and healthy attitudes. The appropriate items were summed, total scores were calculated and means of the subcategories were expressed on four-point scales. The responses on the 16 items were summed to calculate an overall attitude score which was expressed on a four-point scale. The coefficient alpha of the attitude construct was only 0,60 , possibly reflecting the diverse nature of the attitudes measured.

Practices. Twelve items were included to assess a variety of sexual practices of the respondents. These items were analysed individually (i.e. not as a scale), due to the different response options used for every item. The nature and content of the items are given in tables presenting the results.

\section{Procedure}

The data coordinators in the nine different regions were tasked by the Surgeon-General to distribute and coordinate the completion of the questionnaires and return these to the researchers. The respondents in the stratified random sample completed the questionnaires. They completed the questionnaires individually and on completion they returned them in sealed envelopes to the data coordinators. The data coordinators had to ensure that the completed questionnaires were received in sealed envelopes and they were instructed not to open any envelopes. The sealed questionnaires were then sent to the researchers.

\section{RESULTS}

The 4367 respondents had a mean score of $77,28 \%(S D=14,01)$ for knowledge concerning HIV in general (see Table 2). Compared to the other three knowledge subcategories, respondents obtained a low mean score for knowledge relating to occupational health and safety issues $(\mathrm{M}=69,52 \%$; $\mathrm{SD}=33,27)$, whereas a mean score of $73,12 \%(\mathrm{SD}=27,56)$ was obtained for safe sexual practices. Furthermore, they achieved relatively high scores for knowledge concerning condoms $(\mathrm{M}=81,35 \%$ with $\mathrm{SD}=18,80)$.

TABLE 2

DESCRIPTIVE STATISTICS AND ONE-FACTOR REPEATED MEASURES ANOVA OF THE FOUR KNOWLEDGE SUBCATEGORIES' SCORES

\begin{tabular}{lrrrrrrr}
\hline $\begin{array}{l}\text { Knowledge } \\
\text { subcategories }\end{array}$ & Total group & \multicolumn{4}{c}{$\begin{array}{c}\text { Oneway repeated measures } \\
\text { ANOVA for knowledge } \\
\text { construct with corrected values } \\
\text { using Greenhouse-Geisser }\end{array}$} \\
\hline & M (\%) & SD (\%) & N & F & df & p & Eta \\
HIV in general & 77,28 & 14,01 & 4367 & 257,89 & 2,16 & 0,000 & 0,24 \\
OHS & 69,52 & 33,27 & 4367 & & & & \\
Safe practices & 73,12 & 27,56 & 4367 & & & & \\
Condoms & 81,35 & 18,80 & 4367 & & & & \\
\hline
\end{tabular}

Wilks' lambda $=0,86$

$\mathrm{F}(3,4364)=234,03, \mathrm{p}<0,001$

A one-factor repeated measures ANOVA was conducted to compare the means across the four knowledge subcategories for the total sample (Kinnear \& Gray, 1992). Table 2 provides the descriptive statistics for the four levels of the independent variable. Wilks' lambda was equal to $0,86[\mathrm{~F}(3,4364)=234,03$, $\mathrm{p}<0,001]$ and therefore there were statistically significant differences between the centroids of the four knowledge subcategories (see Table 2). The Mauchly sphericity test was used to evaluate whether the data violated the assumption of sphericity, or in other words, the homogeneity of covariance assumption (Field, 2000; Kinnear \& Gray, 1992). The result of Mauchly's test was statistically significant $(\mathrm{W}=0,48, \mathrm{p}<0,001)$ and this indicated that the condition of sphericity was not met. The ANOVA F-test therefore had to be modified to make it more conservative. The correction that was applied to produce a valid F-ratio was the Greenhouse-Geisser epsilon estimate.

The obtained $\mathrm{F}$ using the Greenhouse-Geisser test was statistically significant $[\mathrm{F}(2,16)=257,89, \mathrm{p}<0,001]$. Therefore, statistically significant differences were obtained between the four knowledge subcategories. A small effect size (eta $=0,24)$ was obtained. Paired samples t-tests were subsequently performed to determine between which knowledge subcategories the means differed statistically significantly. The two-tailed probability for every pair was low and this indicated that there were statistically significant differences between all six pairs. 
There was a statistically significant difference between the mean scores of knowledge pertaining to HIV in general and occupational health and safety $(\mathrm{t}=16,04, \mathrm{p}<0,001)$. The soldiers had more knowledge of HIV in general $(\mathrm{M}=77,28 \%)$ than occupational health and safety issues $(\mathrm{M}=69,52 \%)$. There was a statistically significant difference between the mean scores of HIV in general and safe sexual practices $(\mathrm{t}=$ $11,30, p<0,001)$. The soldiers had more knowledge of HIV in general than safe sexual practices $(M=73,12 \%)$, but they had more knowledge of condom use than HIV in general, because $\mathrm{t}$ was equal to $-15,81$ with $\mathrm{p}<0,001$. The soldiers obtained a mean score of $81,35 \%$ for knowledge concerning the use of condoms. There was a statistically significant difference between the mean scores of occupational health and safety and safe sexual practices $(t=-6,24, p<0,001)$. Soldiers had more knowledge of safe sexual practices $(\mathrm{M}=73,12 \%)$ than occupational health and safety issues $(\mathrm{M}=69,52 \%)$. There was a statistically significant difference between the mean scores of occupational health and safety and the use of condoms, because $t$ was equal to $-22,23$ with $p<0,001$. Soldiers had more knowledge of condom use $(\mathrm{M}=81,35 \%)$, than occupational health and safety $(M=69,52 \%)$. Lastly, there was a statistically significant difference between the mean scores of safe sexual practices and condom use $(t=-19,97, p<0,001)$. Soldiers had more knowledge of condom use ( $\mathrm{M}=81,35 \%)$ than safe sexual practices $(M=73,12 \%)$. Thus, soldiers had the most knowledge of condom use, followed by knowledge relating to HIV in general, knowledge of safe sexual practices and they had the least knowledge of occupational health and safety issues.

Attitudes. The total sample of 993 respondents had a mean attitude score of $2,47(\mathrm{SD}=0,29)$ expressed on a four-point scale. The total sample further obtained a high mean attitude score for safe sexual practices $(M=3,20, S D=0,61)$, and condom use $(\mathrm{M}=3,26, \mathrm{SD}=0,54)$ expressed on a four-point scale (see Table 3 ). Neutral scores were obtained for attitudes pertaining to HIV in the workplace $(\mathrm{M}=2,01, \mathrm{SD}=0,63)$, and attitudes concerning the management of HIV/AIDS in the SANDF $(\mathrm{M}=1,98, \mathrm{SD}=0,41)$.

TABLE 3

DESCRIPTIVE STATISTICS AND ONE-FACTOR REPEATED MEASURES ANOVA OF THE FOUR ATTITUDE SUBCATEGORIES' SCORES

\begin{tabular}{lccccccc}
\hline $\begin{array}{l}\text { Attitude } \\
\text { subcategories }\end{array}$ & Total group & \multicolumn{4}{c}{$\begin{array}{c}\text { Oneway repeated measures } \\
\text { ANOVA for attitude } \\
\text { construct with corrected values } \\
\text { using Greenhouse-Geisser }\end{array}$} \\
\hline & M (\%) & SD (\%) & N & F & df & p & Eta \\
\hline Safe practices & 3,20 & 0,61 & 993 & 1736,92 & 2,30 & 0,000 & 0,80 \\
Condoms & 3,26 & 0,54 & 993 & & & & \\
Workplace & 2,01 & 0,63 & 993 & & & & \\
SANDF & 1,98 & 0,41 & 993 & & & & \\
\hline
\end{tabular}

Wilks' lambda $=0,23$

$\mathrm{F}(3,990)=1081,41, \mathrm{p}<0,001$

A one-factor repeated measures ANOVA was conducted to compare the means across the four attitude subcategories for the total sample $(\mathrm{N}=993)$. Wilks' lambda was equal to $0,23[\mathrm{~F}$ $(3,990)=1081,41, \mathrm{p}<0,001]$ and therefore there are statistically significant differences between the centroids of the four attitude subcategories. The result of Mauchly's test was statistically significant $(\mathrm{W}=0,66, \mathrm{p}<0,001)$ and this indicated that the condition of sphericity was not met. After the modification of the ANOVA F-test was made to make it more conservative, the obtained $\mathrm{F}$ using the Greenhouse-Geisser test was statistically significant $[\mathrm{F}(2,30)=1736,92, \mathrm{p}<0,001]$.
Therefore, statistically significant differences were obtained between the four attitude subcategories. A large effect size (eta $=0,80)$ was obtained.

Paired samples t-tests were subsequently performed to determine between which attitude subcategories the means differed statistically significantly. The two-tailed probability for every pair was very low and therefore statistically significant differences were obtained between the means of the following attitude subcategories: Safe sexual practices and condom use $(t=$ $-5,59, p<0,001)$, safe sexual practices and attitudes concerning the management of HIV/AIDS in the workplace $(t=65,46, p<$ $0,001)$, safe sexual practices and attitudes pertaining to HIV/AIDS management in the SANDF $(t=56,16, p<0,001)$, condom use and attitudes concerning the management of HIV/AIDS in the workplace ( $t=70,85, \mathrm{p}<0,001)$, condom use and attitudes pertaining to HIV/AIDS management in the SANDF $(t=61,84, p<0,001)$. A statistically significant difference was not obtained between attitudes concerning the management of HIV/AIDS in the workplace and attitudes pertaining to HIV/AIDS management in the SANDF $(t=1,29, p=0,196)$. The respondents appeared to have more favourable attitude towards condom use $(M=3,26)$ than safe sexual practices $(M=3,20)$, but more favourable attitudes were held for safe sexual practices than attitudes concerning the management of HIV/AIDS in the workplace $(\mathrm{M}=2,01)$. More favourable attitudes were also held for safe sexual practices than attitudes pertaining to HIV/AIDS management in the SANDF $(M=1,98)$. Soldiers had more favourable attitudes toward condom use $(\mathrm{M}=3,26)$, than attitudes concerning the management of HIV/AIDS in the workplace $(\mathrm{M}=2,01)$, or attitudes pertaining to HIV/AIDS management in the SANDF $(\mathrm{M}=1,98)$. Therefore, the respondents had the most favourable attitudes toward condom use, then safe sexual practices, followed by attitudes concerning the management of HIV/AIDS in the workplace. Respondents had the least favourable attitudes toward HIV/AIDS management in the SANDF.

Practices. Analyses for the practice construct were conducted at item level. Cross-tabulations were calculated and the chi-square test was used to determine whether relationships existed per item for the three deployment groups, the dependent variable (Grimm, 1993). Respondents were categorised into one of three deployment groups on the basis of their responses to an item from the biographical section of the KAP questionnaire. This item read 'During the past 12 months, how long were you away from your spouse/partner due to deployments, courses, exercises or work'. The item further stated that if respondents did not have a partner, they should interpret the item as 'How long have you been away from home during the past 12 months?'

The null hypothesis for the chi-square test applied to two-way designs states that the two variables are independent, whereas the alternative hypothesis states that the two variables are associated. Cramèrs' V was also calculated as an index of the strength of the association between the categorical variables (Field, 2000). Siegel and Castellan (1988) argued that Cramér's $\mathrm{V}$ is a useful measure of association due to its wide applicability. Cramér's V was calculated, because $p$ is affected by a large sample size and will therefore yield significant chisquare values in almost all cases, whereas Cramér's V is independent of large sample sizes. Rules of thumb for correlation coefficients such as Cramér's $\mathrm{V}$ are (a) a value of 0 to $+0,3$ indicates no association and are indicative of small effect sizes, (b) a value of $+0,31$ to $+0,6$ equals a weak positive association, whereas (c) a value of $+0,61$ to $+1,0$ reflects a strong positive association (W.C. Koster, personal communication, 27 May 2003).

Number of sexual partners in month prior to data collection The null hypothesis for the chi-square test stated that there is no association between the number of sexual partners that respondents had in the month prior to data collection and the 
length of deployment. No support was found to reject the null hypothesis (see Table 4) and therefore the number of sexual partners that the respondents had in the month prior to data collection was not associated with the length of deployment, $\chi^{2}$ $(10)=12,45, p=0,256$. A small effect size was obtained, because Cramèrs' $\mathrm{V}$ was 0,04 .

TABLE 4

SeXual Practice: 'How Many SEXUal PaRTners DID YOU HAVE IN THE LAST MONTH?'

\begin{tabular}{|c|c|c|c|c|c|c|c|}
\hline \multirow[t]{3}{*}{$\begin{array}{l}\text { Response } \\
\text { options }\end{array}$} & \multicolumn{3}{|c|}{ Deployment group } & \multicolumn{3}{|c|}{$\begin{array}{l}\text { Pearson chi- } \\
\text { square }\end{array}$} & \multirow{2}{*}{$\begin{array}{c}\text { Estimated } \\
\text { effect size } \\
\text { Cramér's } \\
\text { V }\end{array}$} \\
\hline & & & & $\chi^{2}$ & df & & \\
\hline & $\begin{array}{c}\text { Never } \\
\text { deployed } \\
\text { N (\%) }\end{array}$ & $\begin{array}{c}\text { Short } \\
\text { deployment } \\
\text { N (\%) }\end{array}$ & $\begin{array}{c}\text { Lengthy } \\
\text { deployment } \\
\mathrm{N}(\%)\end{array}$ & & & & \\
\hline None & $293(20,8)$ & $178(16,7)$ & $334(20,2)$ & 12,45 & 10 & 0,256 & 0,04 \\
\hline One & $81(5,7)$ & $71(6,7)$ & $120(7,3)$ & & & & \\
\hline $\begin{array}{l}\text { Two and } \\
\text { five }\end{array}$ & $6(0,4)$ & $8(0,8)$ & $11(0,7)$ & & & & \\
\hline $\begin{array}{l}\text { Six and } \\
\text { ten }\end{array}$ & $1008(71,4)$ & $789(74,2)$ & $1162(70,2)$ & & & & \\
\hline $\begin{array}{l}\text { More than } \\
\text { ten }\end{array}$ & $7(0,5)$ & $5(0,5)$ & $12(0,7)$ & & & & \\
\hline Uncertain & $17(1,2)$ & $12(1,1)$ & $16(1,0)$ & & & & \\
\hline
\end{tabular}

Frequency of using condoms. Pearson chi-square was statistically significant $\left[\chi^{2}(4)=28,76\right.$ with $\left.p<0,001\right]$ and it was therefore concluded that there is an association between using condoms the last time respondents had sexual intercourse and length of deployment. More respondents who had deployed for a lengthy period $(37,7 \%)$ indicated that they had used condoms the last time that they had sexual intercourse, than respondents who had deployed for a short period $(30,0 \%)$, or respondents who had not deployed $(30,1 \%)$. Nevertheless, the estimated effect size was small, because Cramèrs' V was only 0,06 . Overall the results indicate that respondents who had deployed for a lengthy period reported less risk taking practices than those respondents who had deployed for a short period, or not at all.

Table 5

Sexual Practice: 'The LaSt time you had SeXual INTERCOURSE, DID YOU OR YOUR PARTNER USE A CONDOM?'

\begin{tabular}{|c|c|c|c|c|c|c|c|}
\hline \multirow[t]{3}{*}{$\begin{array}{l}\text { Response } \\
\text { options }\end{array}$} & \multicolumn{3}{|c|}{ Deployment group } & \multicolumn{4}{|c|}{$\begin{array}{cc}\begin{array}{c}\text { Pearson chi- } \\
\text { Estimated } \\
\text { square }\end{array} & \text { effect size } \\
\text { Cramér's }\end{array}$} \\
\hline & & & & $\chi^{2}$ & df & $\mathrm{p}$ & V \\
\hline & $\begin{array}{l}\text { Never } \\
\text { deployed } \\
\text { N (\%) }\end{array}$ & $\begin{array}{c}\text { Short } \\
\text { deployment } \\
\text { N (\%) }\end{array}$ & $\begin{array}{l}\text { Lengthy } \\
\text { deployment } \\
\text { N (\%) }\end{array}$ & & & & \\
\hline & $436(30,1)$ & $323(30,0)$ & $654(37,7)$ & 28,76 & 4 & 0,000 & 0,06 \\
\hline No & $910(62,8)$ & $673(62,5)$ & $981(56,6)$ & & & & \\
\hline Uncertain & $102(7,0)$ & $81(7,5)$ & $98(5,7)$ & & & & \\
\hline
\end{tabular}

Whether respondents had sexual intercourse under the influence of alcohol. Risk taking behaviour, namely having sexual intercourse under the influence of alcohol, was measured with this item. The results of the chi-square test indicate that the null hypothesis was rejected, because $\chi^{2}(10)=74,88, p<0,001$ (see Table 6). It is therefore concluded that there is an association between whether respondents had sexual intercourse under the influence of alcohol and the length of deployment, but a small effect size was found (Cramèrs' $V=0,1$ ). Overall these results indicate that the respondents who had deployed for a short period $(68,6 \%)$ took fewer sexual risks than respondents who had deployed for a lengthy period $(69,1 \%)$, or those respondents who had not deployed in the year prior to data collection $(70,7 \%)$. These differences are however very small.

TABLE 6

SEXUAL PRACTICE: 'How OFTEN Do YOU HaVe SEX WHEN YOU ARE UNDER THE INFLUENCE OF ALCOHOL?'

\begin{tabular}{|c|c|c|c|c|c|c|c|}
\hline \multirow[t]{3}{*}{$\begin{array}{l}\text { Response } \\
\text { options }\end{array}$} & \multicolumn{3}{|c|}{ Deployment group } & \multicolumn{4}{|c|}{$\begin{array}{cc}\begin{array}{c}\text { Pearson chi- } \\
\text { Estimated } \\
\text { square }\end{array} & \text { effect size } \\
\text { Cramér's }\end{array}$} \\
\hline & & & & $\chi^{2}$ & df & $\mathrm{p}$ & V \\
\hline & $\begin{array}{c}\text { Never } \\
\text { deployed } \\
\text { N (\%) }\end{array}$ & $\begin{array}{c}\text { Short } \\
\text { deployment } \\
\text { N (\%) }\end{array}$ & $\begin{array}{c}\text { Lengthy } \\
\text { deployment } \\
\mathrm{N}(\%)\end{array}$ & & & & \\
\hline \multicolumn{2}{|c|}{ Frequently $63(4,6)$} & $46(4,4)$ & $92(5,5)$ & 74,88 & 10 & 0,000 & 0,10 \\
\hline Often & $273(19,8)$ & $251(24,0)$ & $500(30,0)$ & & & & \\
\hline $\begin{array}{l}\text { Some- } \\
\text { times }\end{array}$ & $639(46,3)$ & $421(40,2)$ & $560(33,6)$ & & & & \\
\hline Seldom & $72(5,2)$ & $55(5,3)$ & $116(7,0)$ & & & & \\
\hline Never & $198(14,3)$ & $142(13,6)$ & $226(13,5)$ & & & & \\
\hline $\begin{array}{l}\text { I do not } \\
\text { have sex }\end{array}$ & $135(9,8)$ & $131(12,5)$ & $175(10,5)$ & & & & \\
\hline
\end{tabular}

Whether respondents used condoms when having sex under influence of alcohol. The result of the chi-square test was statistically significant and therefore the null hypothesis was rejected $\left[\chi^{2}(10)=102,70, p<0,001\right]$. Support was thus found for an association between whether respondents used condoms when having sexual intercourse under the influence of alcohol and the length of deployment. However, a small estimated effect size of Cramèrs' $\mathrm{V}$ equal to 0,16 was obtained. These results indicate that the respondents who had deployed for a lengthy period took fewer sexual risks $(35,3 \%)$ than the respondents who had not deployed $(39,3 \%)$, or who had deployed for a short period $(39,3 \%)$, but these are very small differences. These results are however contradictory to the results obtained with the previous item where the short deployment group reported taking fewer sexual risks in terms of having sexual intercourse under the influence of alcohol.

TABLE 7

SEXUAL PRACTICE: 'IF YOU HAVE SEX WHEN YOU ARE UNDER THE INFLUENCE OF ALCOHOL, HOW OFTEN DO YOU USE A CONDOM?'

\begin{tabular}{|c|c|c|c|c|c|c|c|}
\hline \multirow[t]{3}{*}{$\begin{array}{l}\text { Response } \\
\text { options }\end{array}$} & \multirow{2}{*}{\multicolumn{3}{|c|}{ Deployment group }} & \multicolumn{4}{|c|}{$\begin{array}{cc}\begin{array}{cc}\text { Pearson chi- Estimated } \\
\text { square }\end{array} & \text { effect size } \\
& \text { Cramér's }\end{array}$} \\
\hline & & & & $\chi^{2}$ & df & $\mathrm{p}$ & V \\
\hline & $\begin{array}{l}\text { Never } \\
\text { deployed } \\
\mathrm{N}(\%)\end{array}$ & $\begin{array}{c}\text { Short } \\
\text { deployment } \\
\text { N (\%) }\end{array}$ & $\begin{array}{c}\text { Lengthy } \\
\text { deployment } \\
\text { N (\%) }\end{array}$ & & & & \\
\hline $\begin{array}{l}\text { Fre } \\
\text { quently }\end{array}$ & $211(15,6)$ & $180(17,7)$ & $412(25,1)$ & 102,70 & 10 & 0,000 & 0,11 \\
\hline Often & $97(7,2)$ & $83(8,2)$ & $181(11,0)$ & & & & \\
\hline $\begin{array}{l}\text { Some- } \\
\text { times }\end{array}$ & $437(32,3)$ & $315(30,9)$ & $405(24,7)$ & & & & \\
\hline Seldom & $45(3,3)$ & $51(5,0)$ & $105(6,4)$ & & & & \\
\hline Never & $50(3,7)$ & $35(3,4)$ & $69(4,2)$ & & & & \\
\hline $\begin{array}{l}\text { I do not } \\
\text { have sex }\end{array}$ & $512(37,9)$ & $354(34,8)$ & $469(28,6)$ & & & & \\
\hline
\end{tabular}

Whether respondents requested an HIV/AIDS test in year prior to data collection. The null hypothesis stating that there is not an association between requesting an HIV/AIDS test in the year prior to data collection and the length of deployment was rejected $\left[\chi^{2}\right.$ $(4)=56,48, p<0,001]$. Respondents who had deployed for a lengthy period were more likely to request an HIV/AIDS test than those respondents who had deployed for a short period, or who had not deployed in the year prior to data collection. Nevertheless, a small estimated effect size was found (Cramèrs' $\mathrm{V}=0,08$ ). 
TABLE 8

Sexual Practice: 'IN The LaSt 12 months have you ASKED FOR AN HIV/AIDS TEST?'

\begin{tabular}{|c|c|c|c|c|c|c|c|}
\hline \multirow[t]{3}{*}{$\begin{array}{l}\text { Response } \\
\text { options }\end{array}$} & \multicolumn{3}{|c|}{ Deployment group } & \multicolumn{4}{|c|}{$\begin{array}{cc}\begin{array}{c}\text { Pearson chi- } \\
\text { square }\end{array} & \begin{array}{c}\text { Estimated } \\
\text { effect size } \\
\text { Cramér's }\end{array}\end{array}$} \\
\hline & & & & $\chi^{2}$ & df & $\mathrm{p}$ & V \\
\hline & $\begin{array}{c}\text { Never } \\
\text { deployed } \\
\mathrm{N}(\%)\end{array}$ & $\begin{array}{c}\text { Short } \\
\text { deployment } \\
\text { N (\%) }\end{array}$ & $\begin{array}{c}\text { Lengthy } \\
\text { deployment } \\
\text { N (\%) }\end{array}$ & & & & \\
\hline Yes & $709(48,8)$ & $549(51,0)$ & $1049(60,8)$ & 56,48 & 4 & 0,000 & 0,08 \\
\hline No & $730(50,2)$ & $515(47,9)$ & $650(37,7)$ & & & & \\
\hline Uncertain & $15(1,0)$ & $12(1,1)$ & $25(1,5)$ & & & & \\
\hline
\end{tabular}

Intention to request an HIV/AIDS test when soldiers decided to have a steady relationship with a new sexual partner. The null hypothesis was not rejected, because the chi-square test yielded a statistically non-significant result, namely $\chi^{2}(4)=2,30$ with $p$ $=0,681$. This finding indicated that respondents' responses regarding requesting an HIV/AIDS test when they decide to have a steady relationship and the length of deployment were not associated. Cramèrs' V was 0,02 and therefore the estimated effect size was small.

TABLE 9

SeXual PRactice: 'If You DeCided to have a STEADY RELATIONSHIP, WOULD YOU ASK YOUR PARTNER TO HAVE AN HIV-TEST?'

\begin{tabular}{|c|c|c|c|c|c|c|c|}
\hline \multirow[t]{3}{*}{$\begin{array}{l}\text { Response } \\
\text { options }\end{array}$} & \multicolumn{3}{|c|}{ Deployment group } & \multicolumn{4}{|c|}{$\begin{array}{cc}\begin{array}{c}\text { Pearson chi- } \\
\text { square }\end{array} & \begin{array}{c}\text { Estimated } \\
\text { effect size } \\
\text { Cramér's }\end{array} \\
& \end{array}$} \\
\hline & & & & $\chi^{2}$ & $\mathrm{df}$ & $\mathrm{p}$ & V \\
\hline & $\begin{array}{c}\text { Never } \\
\text { deployed } \\
\text { N (\%) }\end{array}$ & $\begin{array}{c}\text { Short } \\
\text { deployment } \\
\text { N (\%) }\end{array}$ & $\begin{array}{c}\text { Lengthy } \\
\text { deployment } \\
\text { N (\%) }\end{array}$ & & & & \\
\hline Yes & $1162(80,4)$ & $868(80,4)$ & $1382(79,5)$ & 2,30 & 4 & 0,681 & 0,02 \\
\hline No & $179(12,4)$ & $129(11,9)$ & $236(13,6)$ & & & & \\
\hline Uncertain & $105(7,3)$ & $83(7,7)$ & $120(6,9)$ & & & & \\
\hline
\end{tabular}

Protection methods used in six months prior to data collection. This item was used to determine the methods respondents employed to protect themselves from HIV infection in the six months prior to data collection. The respondents had to consider every response option separately and endorse the ones that applied to them. Results are reported per response option (see Table 10).

Chi-square tests were performed to assess whether the proportions of respondents that endorsed the various response options, differed between the three deployment groups. For the response option 'Used condoms every time when having sexual intercourse', the Pearson Chi-square was $\chi^{2}(2)=33,86$ with $\mathrm{p}<0,001$ and therefore the null hypothesis of equal proportions was rejected. A small effect size was found (Cramèrs' $\mathrm{V}=0,09$ ). For the second response option, namely 'Used condoms some of the time when having sexual intercourse' the chi-square test was $\chi^{2}(2)=7,71$ with $p=0,021$ and therefore the null hypothesis was rejected. Thus, the proportion of respondents across the three deployment groups also differed statistically significantly in terms of using condoms some of the time when having sexual intercourse as a method to prevent HIV infection. The largest proportion of respondents who endorsed this method of prevention had deployed between two months and a year. However, the estimated effect size was small, because Cramèrs' V was only
0,04 . The null hypothesis in the case of abstaining from sexual intercourse as a method to prevent HIV infection could not be rejected, because the chi-square test yielded a statistically non-significant result $\left[\chi^{2}(2)=5,60, p=0,061\right]$. Similarly, no support was found to reject the null hypothesis for 'Done other things than having sexual intercourse'. The chi-square test yielded a value of $\chi^{2}(2)=4,22$ with $p=0,121$. A small estimated effect size was obtained (Cramèrs' $V=0,03$ ). Furthermore, no statistically significant differences were obtained between the proportions of the three deployment groups who endorsed the response option 'Had only one sexual partner', because the chi-square test yielded a value of $\chi^{2}(2)=1,56$ with $p=0,459$. Cramèrs' $V$ yielded a small effect size $(0,02)$.

TABle 10

SeXual PRactice: 'What have you done IN THE PAST SIX MONTHS TO PROTECT YOURSELF FROM BEING INFECTED WITH HIV/AIDS?'

\begin{tabular}{|c|c|c|c|c|c|c|c|}
\hline \multirow[t]{3}{*}{$\begin{array}{l}\text { Response } \\
\text { options }\end{array}$} & \multicolumn{3}{|c|}{ Deployment group } & \multicolumn{2}{|c|}{$\begin{array}{l}\text { Pearson chi- } \\
\text { square }\end{array}$} & \multicolumn{2}{|c|}{$\begin{array}{r}\text { Estimated } \\
\text { effect size } \\
\text { Cramér's }\end{array}$} \\
\hline & & & & $\chi^{2}$ & df & $\mathrm{p}$ & V \\
\hline & $\begin{array}{c}\text { Never } \\
\text { deployed } \\
\text { N (\%) }\end{array}$ & $\begin{array}{c}\text { Short } \\
\text { deployment } \\
\text { N (\%) }\end{array}$ & $\begin{array}{c}\text { Lengthy } \\
\text { deployment } \\
\text { N (\%) }\end{array}$ & & & & \\
\hline $\begin{array}{l}\text { Used condoms } \\
\text { every time } \\
\text { when having } \\
\text { sexual intercourse }\end{array}$ & $576(39,1)$ & $444(40,3)$ & $857(48,5)$ & 33,86 & 2 & 0,000 & 0,09 \\
\hline $\begin{array}{l}\text { Used condoms } \\
\text { some of the } \\
\text { time when having } \\
\text { intercourse }\end{array}$ & $\begin{array}{l}283(19,2) \\
g\end{array}$ & $213(19,3)$ & $402(22,8)$ & 7,71 & 2 & 0,021 & 0,04 \\
\hline $\begin{array}{l}\text { Did not } \\
\text { have sex }\end{array}$ & $259(17,6)$ & $179(16,3)$ & $347(19,6)$ & 5,60 & 2 & 0,061 & 0,04 \\
\hline $\begin{array}{l}\text { Done other } \\
\text { things than } \\
\text { having sex }\end{array}$ & $164(11,1)$ & $113(10,3)$ & $224(12,7)$ & 4,22 & 2 & 0,121 & 0,03 \\
\hline $\begin{array}{l}\text { Had only one } \\
\text { sexual partner }\end{array}$ & $930(63,2)$ & $699(63,5)$ & $1086(61,5)$ & 1,56 & 2 & 0,459 & 0,02 \\
\hline $\begin{array}{l}\text { Tried to drink } \\
\text { less when out } \\
\text { socialising }\end{array}$ & $195(13,2)$ & $162(14,7)$ & $297(16,8)$ & 8,10 & 2 & 0,017 & 0,04 \\
\hline Other & $123(8,4)$ & $89(8,1)$ & $150(8,5)$ & 0,15 & 2 & 0,929 & 0,01 \\
\hline
\end{tabular}

The proportions of respondents that endorsed the response option 'Try to drink less when out socialising' differed statistically significantly $\left[\chi^{2}(2)=8,10, p=0,017\right]$. Therefore the null hypothesis of equal proportions was rejected. The estimated effect size was small (Cramèrs' $\mathrm{V}=0,04$ ). Results reported in Table 5.17 show that $13,2 \%$ of the respondents in the never deployed group, $14,7 \%$ of the respondents in the short deployment group and $16,8 \%$ of the respondents in the lengthy deployment group tried to drink less when socialising. The results of the practice construct so far favour the lengthy deployment group.

Taking sufficient care to protect sexual partners from HIV infection. No support was found to reject the null hypothesis, because $\chi^{2}(8)=12,16, p=0,144$ which was statistically nonsignificant. A small effect size was obtained, because Cramèrs' $\mathrm{V}$ was 0,04 .

Soldiers' beliefs of having a personal responsibility to stop the spread of HIVAIDS. The Pearson chi-square was statistically significant $\left[\chi^{2}(8)=18,30, p=0,019\right]$. Therefore the null hypothesis stating that there is no association between soldiers' beliefs of having a personal responsibility to stop the spread of HIV/AIDS and length of deployment was rejected. It is thus concluded that there is an association between soldiers' beliefs of having a responsibility to stop the spread of HIV/AIDS and length of deployment, although the estimated effect size was small (Cramèrs' $V=0,05$ ). Respondents who had not deployed were 
more likely to agree with the statement $(90,5 \%)$ than respondents who had deployed for either a short $(89,9 \%)$, or a lengthy period $(88,6 \%)$, but these were small differences.

TABLE 11

SEXUAL PRACTICE: 'I TRY TO DO WHATEVER I CAN TO PROTECT MY SEXUAL PARTNERS FROM HIV INFECTION'

\begin{tabular}{|c|c|c|c|c|c|c|c|}
\hline \multirow[t]{3}{*}{$\begin{array}{l}\text { Response } \\
\text { options }\end{array}$} & \multicolumn{3}{|c|}{ Deployment group } & \multicolumn{4}{|c|}{$\begin{array}{cc}\begin{array}{c}\text { Pearson chi- } \\
\text { Estimated } \\
\text { square }\end{array} & \text { effect size } \\
\text { Cramér's }\end{array}$} \\
\hline & & & & $\chi^{2}$ & df & $\mathrm{p}$ & V \\
\hline & $\begin{array}{c}\text { Never } \\
\text { deployed } \\
\text { N (\%) }\end{array}$ & $\begin{array}{c}\text { Short } \\
\text { deployment } \\
\text { N (\%) }\end{array}$ & $\begin{array}{c}\text { Lengthy } \\
\text { deployment } \\
\text { N (\%) }\end{array}$ & & & & \\
\hline $\begin{array}{l}\text { Strongly } \\
\text { agree }\end{array}$ & $655(46,5)$ & $489(46,9)$ & $755(46,4)$ & 12,16 & 8 & 0,144 & 0,04 \\
\hline Agree & $478(33,9)$ & $365(35,0)$ & $616(37,8)$ & & & & \\
\hline Disagree & $53(3,8)$ & $37(3,6)$ & $62(3,8)$ & & & & \\
\hline $\begin{array}{l}\text { Strongly } \\
\text { disagree }\end{array}$ & $31(2,2)$ & $23(2,2)$ & $32(2,0)$ & & & & \\
\hline Uncertain & $191(13,6)$ & $128(12,3)$ & $163(10,0)$ & & & & \\
\hline
\end{tabular}

TABLE 12

SEXUAL PRACTICE: 'I BELIEVE I HAVE A RESPONSIBILITY TO HELP STOP THE SPREAD OF HIV/AIDS'

\begin{tabular}{lcccc}
\hline $\begin{array}{l}\text { Response } \\
\text { options }\end{array}$ & Deployment group & $\begin{array}{c}\text { Pearson chi- } \\
\text { square }\end{array}$ & $\begin{array}{c}\text { Estimated } \\
\text { effect size } \\
\text { Cramér's }\end{array}$ \\
& $\chi^{2}$ & df & p & V
\end{tabular}

\begin{tabular}{lccccccc}
\hline & $\begin{array}{c}\text { Never } \\
\text { deployed } \\
\text { N (\%) }\end{array}$ & $\begin{array}{c}\text { Short } \\
\text { deployment } \\
\text { N (\%) }\end{array}$ & $\begin{array}{c}\text { Lengthy } \\
\text { deployment } \\
\text { N (\%) }\end{array}$ & & & & \\
\hline $\begin{array}{l}\text { Strongly } \\
\text { agree }\end{array}$ & $831(58,5)$ & $573(54,6)$ & $894(54,3)$ & 18,30 & 8 & 0,019 & 0,05 \\
Agree & $455(32,0)$ & $371(35,3)$ & $564(34,3)$ & & & & \\
Disagree & $41(2,9)$ & $30(2,9)$ & $82(5,0)$ & & & & \\
$\begin{array}{l}\text { Strongly } \\
\text { disagree }\end{array}$ & $38(2,7)$ & $36(3,4)$ & $49(3,0)$ & & & & \\
Uncertain & $55(3,9)$ & $40(3,8)$ & $57(3,5)$ & & & & \\
\hline
\end{tabular}

Soldiers' beliefs that every SANDF/DoD member has a responsibility to stop the spread of HIV/AIDS. No support was found to reject the null hypothesis, because the chi-square test was not statistically significant $\left[\chi^{2}(8)=7,71, p=0,462\right]$. Therefore the two variables, namely respondents' beliefs that every SANDF/DoD member has a responsibility to stop the spread of HIV/AIDS and length of deployment were not associated. A small effect size was obtained (Cramèrs' V = 0,03).

TABLE 13

SeXual Practice: 'Every Member of THE SANDF/DoD haS A RESPONSIBILITY TO STOP THE SPREAD OF HIV/AIDS'

\begin{tabular}{|c|c|c|c|c|c|c|c|}
\hline \multirow[t]{3}{*}{$\begin{array}{l}\text { Response } \\
\text { options }\end{array}$} & \multicolumn{3}{|c|}{ Deployment group } & \multicolumn{3}{|c|}{$\begin{array}{l}\text { Pearson chi- } \\
\text { square }\end{array}$} & \multirow{2}{*}{$\begin{array}{c}\text { Estimated } \\
\text { effect size } \\
\text { Cramér's } \\
\text { V }\end{array}$} \\
\hline & & & & $\chi^{2}$ & df & $\mathrm{p}$ & \\
\hline & $\begin{array}{c}\text { Never } \\
\text { deployed } \\
\text { N (\%) }\end{array}$ & $\begin{array}{c}\text { Short } \\
\text { deployment } \\
\text { N (\%) }\end{array}$ & $\begin{array}{c}\text { Lengthy } \\
\text { deployment } \\
\mathrm{N}(\%)\end{array}$ & & & & \\
\hline $\begin{array}{l}\text { Strongly } \\
\text { agree }\end{array}$ & $899(63,8)$ & $654(62,1)$ & $982(60,4)$ & 7,71 & 8 & 0,462 & 0,03 \\
\hline Agree & $371(26,3)$ & $302(28,7)$ & $489(30,1)$ & & & & \\
\hline Disagree & $51(3,6)$ & $30(2,8)$ & $57(3,5)$ & & & & \\
\hline $\begin{array}{l}\text { Strongly } \\
\text { disagree }\end{array}$ & $45(3,2)$ & $38(3,6)$ & $47(2,9)$ & & & & \\
\hline Uncertain & $44(3,1)$ & $29(2,8)$ & $50(3,1)$ & & & & \\
\hline
\end{tabular}

Soldiers' sense of responsibility towards their friends' sexual health. No support was found to reject the null hypothesis and therefore soldiers' sense of responsibility towards their friends' sexual health was not associated with the length of deployment $\left[\chi^{2}(8)\right.$ $=12,57, p=0,128]$. A small effect size was obtained, because Cramèrs' $\mathrm{V}$ was 0,04 .

TABLE 14

SEXUAL PRACTICE: 'I FEel RESPONSIBLE TO CHALLENGE OR QUESTION MY FRIENDS WHEN THEY TAKE SEXUAL RISKS'

\begin{tabular}{|c|c|c|c|c|c|c|c|}
\hline \multirow[t]{3}{*}{$\begin{array}{l}\text { Response } \\
\text { options }\end{array}$} & \multicolumn{3}{|c|}{ Deployment group } & \multicolumn{4}{|c|}{$\begin{array}{cc}\begin{array}{cc}\text { Pearson chi- } \\
\text { square }\end{array} & \begin{array}{c}\text { effect simated } \\
\text { Cramér's }\end{array} \\
& \text { Crame }\end{array}$} \\
\hline & & & & $\chi^{2}$ & df & $\mathrm{p}$ & V \\
\hline & $\begin{array}{c}\text { Never } \\
\text { deployed } \\
\mathrm{N}(\%)\end{array}$ & $\begin{array}{c}\text { Short } \\
\text { deployment } \\
\text { N (\%) }\end{array}$ & $\begin{array}{c}\text { Lengthy } \\
\text { deployment } \\
\text { N (\%) }\end{array}$ & & & & \\
\hline $\begin{array}{l}\text { Strongly } \\
\text { agree }\end{array}$ & $539(37,3)$ & $400(37,1)$ & $647(38,3)$ & 12,57 & 8 & 0,128 & 0,04 \\
\hline Agree & $605(41,9)$ & $461(42,8)$ & $758(44,9)$ & & & & \\
\hline Disagree & $143(9,9)$ & $113(10,5)$ & $151(8,9)$ & & & & \\
\hline $\begin{array}{l}\text { Strongly } \\
\text { disagree }\end{array}$ & $53(3,7)$ & $32(3,0)$ & $51(3,0)$ & & & & \\
\hline Uncertain & $105(7,3)$ & $71(6,6)$ & $83(4,9)$ & & & & \\
\hline
\end{tabular}

Intention to practice safe sexual behaviour. This item was included to assess the respondents' intention to practice safe sexual behaviour and the results are reported in Table 15. The respondents had to consider every response option separately and endorse the ones that applied to them. In Table 15 the results of the chi-square tests for equal proportions are reported. No support was found to reject the null hypotheses for the following response options, namely to (a) refuse to have sex unless condoms were used, (b) try to convince the sexual partner into doing other things, (c) forget about condoms and have sex anyway, (d) be unsure what to do, and (e) do something else than what was stated in the questionnaire. Therefore the proportion of respondents from every deployment group that endorsed the aforementioned responses did not differ statistically significantly and estimated effect sizes were small (Cramèrs' $\mathrm{V}$ ranging from 0,03 to 0,01 ).

TABLE 15

SEXUAL PRACTICE: 'IF YOU WERE WITH SOMEONE WHO WANTED TO HAVE SEX WITH YOU, WITHOUT USING A CONDOM, AND YOU WERE NOT SURE IF THEY HAD HIV/AIDS, WHAT WOULD YOU DO?'

\begin{tabular}{|c|c|c|c|c|c|c|c|}
\hline \multirow[t]{3}{*}{$\begin{array}{l}\text { Response } \\
\text { options }\end{array}$} & \multirow{2}{*}{\multicolumn{3}{|c|}{ Deployment group }} & \multirow{2}{*}{\multicolumn{2}{|c|}{$\begin{array}{l}\text { Pearson chi- } \\
\text { square }\end{array}$}} & \multirow{2}{*}{\multicolumn{2}{|c|}{$\begin{array}{r}\text { Estimated } \\
\text { effect size } \\
\text { Cramér's } \\
\text { p } \quad \text { V }\end{array}$}} \\
\hline & & & & & & & \\
\hline & $\begin{array}{c}\text { Never } \\
\text { deployed } \\
\text { N (\%) }\end{array}$ & $\begin{array}{c}\text { Short } \\
\text { deployment } \\
\text { N (\%) }\end{array}$ & $\begin{array}{c}\text { Lengthy } \\
\text { deployment } \\
\text { N (\%) }\end{array}$ & & & & \\
\hline $\begin{array}{l}\text { Refuse to have } \\
\text { sex unless a } \\
\text { condom was used }\end{array}$ & $754(51,2)$ & $567(51,5)$ & $954(54,0)$ & 2,91 & 2 & 0,233 & 0,03 \\
\hline $\begin{array}{l}\text { Try to convince } \\
\text { my partner to } \\
\text { use a condom }\end{array}$ & $320(21,7)$ & $269(24,5)$ & $478(27,0)$ & 12,24 & 2 & 0,002 & 0,05 \\
\hline $\begin{array}{l}\text { Try and talk my } \\
\text { partner into doing } \\
\text { other things }\end{array}$ & $\mathrm{g}^{79(5,4)}$ & $71(6,5)$ & $103(5,8)$ & 1,37 & 2 & 0,505 & 0,02 \\
\hline $\begin{array}{l}\text { Forget about } \\
\text { condoms and } \\
\text { have sex anyway }\end{array}$ & $41(2,8)$ & $30(2,7)$ & $53(3,0)$ & 0,22 & 2 & 0,895 & 0,01 \\
\hline $\begin{array}{l}\text { I don't know } \\
\text { what I would do }\end{array}$ & $79(5,4)$ & $43(3,9)$ & $86(4,9)$ & 2,95 & 2 & 0,228 & 0,03 \\
\hline Not applicable & $286(19,4)$ & $205(18,6)$ & $265(15,0)$ & 12,48 & 2 & 0,002 & 0,05 \\
\hline Other & $61(4,1)$ & $48(4,4)$ & $56(3,2)$ & 3,36 & 2 & 0,186 & 0,03 \\
\hline
\end{tabular}


However, the null hypothesis was rejected for the response option, namely 'Try to convince my partner to use a condom' $\left[\chi^{2}\right.$ $(2)=12,24, p=0,002]$ and therefore the proportion of respondents who endorsed this response did differ statistically significantly across the three deployment groups. A small estimated effect size was found (Cramèrs' $V=0,05$ ). Respondents who had deployed for a lengthy period were more likely to endorse this response option $(27,0 \%)$, than respondents who had not deployed $(21,7 \%)$, or who had deployed for a short period $(24,5 \%)$. The responses of those respondents who had deployed for a lengthy period were therefore less risky than respondents who had deployed for a short period, or those respondents who had not deployed in the year prior to data collection. These results once again favour the lengthy deployment group.

\section{DISCUSSION}

Several studies were cited to indicate that soldiers' high vulnerability had negative consequences for themselves and for the organisation. Yet, it was also shown that not enough had been done to address HIV/AIDS among deployed SANDF soldiers. It was further argued that the large numbers of migrant workers within the SANDF necessitated a unique HIV prevention programme. The aim of this study was therefore to determine the levels of knowledge, attitudes and reported risk practices amongst soldiers. Overall the results indicated that soldiers were taking sexual risks, although they had high levels of knowledge and had healthy attitudes concerning HIV/AIDS.

\section{Knowledge}

The soldiers had high scores for the various knowledge subcategories. They had high mean scores for knowledge pertaining to HIV in general. These high scores were however expected, because the items that constituted this subcategory typically assessed general HIV knowledge which is similar to the information that is widely disseminated in the media, such as the news, documentaries, awareness-raising campaigns, posters, industrial theatre, television soap operas and magazines. In comparison to the scores of the other three knowledge subcategories, soldiers had the lowest knowledge score for the occupational health and safety subcategory. The results pertaining to knowledge of safe sexual practices indicated that the soldiers knew how to prevent HIV or STI infection through safe sexual practices, because the mean knowledge score of safe sexual practices was high. The soldiers' highest mean score for knowledge related to condom use.

Although the levels of knowledge for three of the four subcategories were high, complacency could prove to be a serious mistake, because large standard deviation scores were obtained. Therefore, continued awareness raising and education efforts are advisable, because Jackson (2002) stated that HIV/AIDS education should be explicit and be repeated to remain effective. Particular attention should be paid to increasing the level of knowledge pertaining to occupational health and safety.

\section{Attitudes}

The results of several studies indicated that the types of behaviour individuals engage in could be predicted from the types of attitudes held (Bedworth \& Bedworth, 1992; Borlard \& Hill, 1997; Diamenu \& Nyaku, 1998; Gregson, Zhuwau, Anderson \& Chandiwana, 1998; Jaramillo, 1998; Jemmott, Jemmott \& Fong, 1992; Kalua, 2001; Naslund, 1997; Petterson, Kristal \& White, 1996). The results of this study indicated that the overall attitude score reflected healthy attitudes and consequently one can expect that these favourable attitudes towards disease prevention will lead to soldiers engaging in healthy behaviours.

The SANDF should however establish more trust in their existing HIV prevention services to ensure more favourable attitudes towards the management of HIV/AIDS in the workplace, because ambivalent attitudes concerning HIV/AIDS in the workplace were reported by soldiers. Therefore more attention should be given to improving attitudes towards (a) working alongside HIVpositive soldiers, (b) sharing a room with HIV-positive soldiers during military or other courses, (c) revealing HIV-status to colleagues and supervisors, and (d) accepting the HIV-positive status of colleagues. Ambivalent attitudes concerning the SANDF's management of the disease were also identified. Thus, the SANDF should improve the attitudes of their employees towards (a) tolerance and respectfulness of HIV-positive soldiers, (b) ensuring job security of HIV-positive soldiers, (c) HIV/AIDS testing within the SANDF/DoD, and (d) preferential medical treatment of HIV/AIDS above other serious illnesses. The interventions to address these ambivalent attitudes should be linked to the existing SANDF HIV prevention programmes. This is deemed necessary, because Bok and Morales (1997) noted that those intervention strategies that were linked to existing programmes run by the organisation had a greater likelihood of being sustained.

Continued prevention efforts are further required to change attitudes favourably towards both HIV/AIDS concerns within the workplace, and the management of the disease within the SANDF. According to UNAIDS (1998a; 2003a) the impact of these continued prevention efforts depend on an environment of openness and inclusion that enables all employees to undergo voluntary testing, seek and receive treatment, alter their own behaviour and become partners in the battle against HIV/AIDS. Therefore the SANDF must create a nonstigmatising and non-discriminatory environment, because destigmatisation and acceptance of soldiers with HIV are essential components that have a strong bearing on prevention and appropriate care. Creating a non-stigmatising and nondiscriminatory environment within the SANDF should start with complete confidentiality for HIV testing (UNAIDS, 2003a). The involvement of soldiers living with HIV/AIDS can also assist in eliminating the barriers of stigma and discrimination within the SANDF.

\section{Practices}

A disturbing finding, especially after a high level of knowledge and healthy attitudes towards safe sexual practices and the use of condoms were indicated, was the finding that most soldiers $(71,65 \%)$ had between six and ten sexual partners in the month prior to data collection. Almost one percent of the sample $(0,6 \%)$ reported that they had more than ten sexual partners in the month prior to data collection. A small percentage of the soldiers $(1,09 \%)$ reported that they did not know how many sexual partners they had had in the last month. This is an alarming finding. The question may be asked, why don't these soldiers know how many sexual partners they had only recently? It may be that the soldiers did not answer this item honestly, because it is very personal.

The credibility of some of the results regarding practices should be considered, because contradictory results were obtained. For instance, results obtained from the demographic information sheet indicated that $47,16 \%$ of the soldiers were married and that they had only one sexual partner. But the item measuring the number of sexual partners that the soldiers had had in the month prior to data collection indicated that $71,65 \%$ of the soldiers had had between six and ten sexual partners in the month prior to data collection. Also, when the soldiers reported what methods they had used to protect themselves from HIV infection in the six months prior to data collection, $62,73 \%$ reported that they had practised monogamy. Practising monogamy was the highest rated of those prevention methods listed in the KAP questionnaire. The soldiers may thus have inflated the number of sexual partners for the purpose of making them look powerful, because it was explained earlier that the emphasis on sexual prowess as the 'mark of a man' motivated soldiers to pursue sex with many partners. 
Other risk behaviour was also reported. The majority of soldiers $(60,22 \%)$ reported that they had not used condoms the last time that they had had sexual intercourse. However, $47,16 \%$ of the sample reported that they were married and monogamous, and then the use of condoms to prevent HIV infection appears unnecessary. Also, $62,03 \%$ of the soldiers reported that they did use condoms regularly when having sexual intercourse under the influence of alcohol. This is an important finding, because $69,47 \%$ of the soldiers reported that they frequently, often or sometimes had sexual intercourse under the influence of alcohol. The use of condoms every time $(42,63 \%)$ and some of the time $(20,43 \%)$ during sexual intercourse to prevent HIV infection, were the second and third highest rated prevention methods that the soldiers had used in the six months prior to data collection. Also, more than half of the sample reported that they would refuse to have sexual intercourse with someone of unknown HIV status, unless condoms were used, whereas a quarter of the sample stated that they would try to convince their partners with an unknown HIV status to use condoms. But $2,83 \%$ of the soldiers reported that they would not use condoms when having sexual intercourse with someone of unknown HIV status. Lastly, a large percentage of the sample $(80,1 \%)$ reported that they would ask a new sexual partner to take an HIV/AIDS test when they decided to have a steady relationship. But only $53,53 \%$ of the soldiers reported that they had requested an HIV/AIDS test in the year prior to data collection.

In addition to the identification of soldiers' risk practices, their beliefs regarding HIV prevention were obtained. The majority of the soldiers $(82,17 \%)$ were of the opinion that they did take sufficient care of their sexual partners to protect them from HIV infection. The majority of the soldiers $(89,67 \%)$ further believed that they had a personal responsibility to stop the spread of HIV/AIDS and $80,77 \%$ of the soldiers also considered themselves responsible to challenge or question their friends when the lastmentioned parties were taking sexual risks. Most soldiers $(90,47 \%)$ believed that every SANDF/DoD member has a responsibility to stop the spread of the disease. Given the contradictory findings, additional HIV/AIDS prevention and care initiatives should be made available to the SANDF employees and their dependents (FHI Focus On, 2001). Harrison, Smit and Myer (2000) advised that effective behavioural riskreduction programmes used skills-based education and training methods with a theoretical basis. Lastly, one of the basic rules of HIV prevention is that it is best to start early with awareness raising and education (UNAIDS, 2003a; FHI Focus On, 2001). Reaching members should therefore start before soldiers depart for work overseas or away from home.

\section{Conclusion}

The main contribution of the research project was to highlight the vulnerability of deployed soldiers and to identify the need for a unique HIV prevention programme for this population group. Also, the levels of knowledge, attitudes and practices of soldiers who had deployed for lengthy periods were determined and compared with soldiers who had not deployed or had deployed for less than a month. These findings are useful to HIV prevention practitioners and programme developers who need to develop additional HIV/AIDS prevention programmes within the SANDF.

Therefore, although employers alone cannot stop the spread of HIV/AIDS, they can contribute resources and skills, raise awareness, help influence employee attitudes and sexual behaviours, and provide medical services. The workplace offers a structured environment for sharing information, implementing interventions and reinforcing acceptable behaviour (Bennis, Spreitzer \& Cummings, 2001). Furthermore, addressing deployed soldiers' needs in terms of HIV prevention and AIDS care, not only helps sustain the workforce, but also enhances the organisation's image by keeping it an attractive employer to prospective applicants.

\section{REFERENCES}

Bedworth, A.E., \& Bedworth, D.A. (1992). The profession and practice of health education. Dubuque: Wm C Brown.

Bennis, W., Spreitzer, G.M., \& Cummings, T.G. (2001). The future of leadership. Today's top leadership thinkers speak to tomorrow's leaders. San Francisco: Jossey-Bass.

Bielfeld, R.I. (2002). National survey on the knowledge, attitudes and practices of DoD members with regard to HIV and AIDS (MPI/C/2002/0006/A, dd April 2002). Pretoria, South Africa: South African Military Health Service, Military Psychological Institute, Military Health Research Centre, Research Consultancy Department.

Bok, M., \& Morales, J. (1997). Effective HIV prevention interventions for adolescents and young adults: a theoretical approach. Journal of HIV/AIDS Prevention and Education for Adolescents and Children, 1 (3), 9-35.

Borlard, R., \& Hill, D. (1997). Initial impact of the new Australian tobacco health warnings on knowledge and beliefs. Tobacco Control, 6 (4), 317-325.

Bruwer, N., \& Van Dyk, G.A.J. (2005). The South African peacekeeping experience: A comparative analysis. South African Journal of Industrial Psychology, 31 (2), 30 - 39.

Craig, I., \& Le Roux, I. (2002). HIV/AIDS. [CD-ROM]. University of Pretoria.

Curran, L., \& Munywoki, M. (2002). HIV/AIDS and uniformed services: Stocktaking of activities in Kenya, Tanzania and Uganda. Retrieved August 1, 2003 from the World Wide Web: http://www.unaids.org

De Beer, J.C. (2002). Milestone report: A study on the experience of the use of time during operational deployments. (MPI/R/516/2, dd August 2003). Pretoria, South Africa: South African Military Health Service, Military Psychological Institute, Military Health Research Centre, Chaplaincy Research Department.

Department of Defence. (2002). HIV/AIDS Policy Information Brochure. Pretoria: Department of Defence.

Diamenu, S.K., \& Nyaku, A.A. (1998). Guinea worm disease - a chance for successful eradication in the Volta Region, Ghana. Social Science and Medicine, 47 (3), 405-410.

Duckett, M. (2001). Migrants' Right to Health. UNAIDS Best Practice Collection. [CD-ROM]. UNAIDS library of current documents.

FHI Focus On (2001). HIV/AIDS prevention in the workplace. Retrieved November 8, 2002 from the World Wide Web: http://www.fhi.org

Field, A. (2000). Discovering statistics using SPSS for Windows: Advanced techniques for the beginner. London: SAGE.

Gregson, S., Zhuwau, T., Anderson, R.M., \& Chandiwana, S.K. (1998). Is there evidence for behavioural change in response to AIDS in rural Zimbabwe? Social Science and Medicine, 46 (3), 321-330.

Harrison, A., Smit, J.A., \& Myer, L. (2000). Prevention of HIV/AIDS in South Africa: A review of behaviour change interventions, evidence and options for the future. South African Journal of Science, 96, 285-290.

Hyde, S., Moeketsi, T., \& White, S. (1998). South African Military Health Service AIDS/STD KAP survey and needs assessment report. Pretoria: AET.

Jackson, H. (2002). AIDS Africa: Continent in crisis. Harare, Zimbabwe: SAfAIDS.

Jaramillo, E. (1998). Pulmonary tuberculosis and health-seeking behaviour: How to get delayed diagnosis in Cali, Colombia. Tropical Medicine and International Health, 3 (2), 138 - 144.

Jemmott, J.B., Jemmott, L.S., \& Fong, G.T. (1992). Reductions in HIV risk-associated sexual behaviors among Black male adolescents: Effects of an AIDS prevention intervention. American Journal of Public Health, 82 (3), 372 - 377.

Kalua, F.K. (2001). The relationship between knowledge, attitudes and practices of caregivers, and food hygiene in day care centres. Unpublished master's dissertation, Technikon Pretoria. 
Kinnear, P.R., \& Gray, C.D. (1992). SPSS/PC+ made simple. East Sussex, UK: Lawrence Erlbaum.

Lurie, M. (1999). Mines in South Africa. In M. Schoofs, All the glitters: How HIV caught fire in South Africa (pp. 5-8). The Village Voice.

Mail and Guardian. (2000, March 31). UNAIDS/WHO 1999 estimate. Pretoria.

Malan, M. (1997). Towards sounder investments in developing African Peace Operations capabilities. African Security Review, 6 (2). Retrieved June 8, 2002 from the World Wide Web: http//www.iss.co.za

Masibambisane. (2001). Educational Officers HIV Training. Pretoria, South Africa: South African Military Health Service, Military Psychological Institute.

Naslund, G.K. (1997). Relationship between health behaviour, knowledge and beliefs among Swedish-blue collar workers. Scandinavian Journal of Social Medicine, 25 (2), 100-110.

Okee-Obong, J. B. (2001). A comparative analysis of the social and historical roots of the HIV/AIDS epidemic in Uganda and South Africa. Paper presented at the AIDS in Context Conference held at the University of the Witwatersrand, Johannesburg, South Africa.

Olayinka, B.A., \& Osho, A.A. (1997). Changes in attitudes, sexual behaviour and risk of HIV/AIDS transmission in southwest Nigeria. East African Medical Journal, 74 (9), 554-560.

Petterson, R.E., Kristal, A.R., \& White, E. (1996). Do beliefs, knowledge and perceived norms about diet and cancer predict dietary change? American Journal of Public Health, 86 (10), 1394-1400.

Shtarkshall, R. \& Soskolne, V. (2000). Migrant populations and HIV/AIDS. [CD-ROM]. UNAIDS library of current documents. Siegel, S., \& Castellan, N.J. (1988). Nonparametric statistics for the Behavioural Sciences (2nd ed.). New York: McGraw-Hill.

UNAIDS. (1998a). AIDS and the military: UNAIDS point of view. UNAIDS Best Practice Collection. [CD-ROM]. Civil-Military Alliance to combat HIV and AIDS, Technical Reference Library.

UNAIDS. (1998b). HIV/AIDS and Human Rights: International Guidelines (HR/PUB/98/1). New York: United Nations.

UNAIDS. (2001a). Population mobility and AIDS. [CD-ROM]. UNAIDS library of current documents.

UNAIDS. (2002). Report on the global HIV/AIDS epidemic 2002. Retrieved July 2, 2002 from the World Wide Web: http://www.unaids.org

UNAIDS. (2003a). AIDS epidemic update. December 2003. Retrieved December 20, 2003 from the World Wide Web: http://www.unaids.org

United Nations General Assembly Special Session on HIV/AIDS (2002). Monitoring the Declaration of Commitment on HIV/AIDS: Guidelines on construction of core indicators. Geneva, Switzerland: UNAIDS.

Van Breda, A.D., Siwisa, L., Potgieter, H., \& Banda, A. (1999). Project Resilience: 2 SAI Bn. Pretoria, South Africa: South African Military Health Service, Military Psychological Institute, Military Health Research Centre, Social Work Research Department. 